\title{
Intellectual Property Rights in Nigerian Business Environment: Challenges and Prospects
}

\section{Carl Osunde*}

Dean of Studies, Onitsha Business School, Anambra State, Nigeria

\begin{abstract}
The intellectual property rights system is key to protect assets of micro, small and medium enterprises. Protecting an invention is one of the key roles that intellectual property rights plays in innovative business ventures. To remain ahead of competitors, entrepreneurs must either continuously introduce innovative products and services or make improvements to the quality of existing products and services. The author of this research study found out that intellectual property rights protect innovations, encourage research and development (R\&D) and boost profits of micro, small and medium enterprises, however, there are numerous challenges in the enforcement of intellectual property rights such as counterfeit products which are abundant in the Nigerian market.
\end{abstract}

Keywords: Intellectual property rights; Licence; Patent; National agency for food; Drug administration and control; Counterfeit; Research and development (R\&D) and innovation

JEL Classification: JEL: M10 - General

\section{Introduction}

Intellectual property (IP) refers to original creations such as inventions; literary and artistic works; designs; and symbols, names and images used in commerce [1]. Intellectual property is protected in law to create exclusive right to the inventor or creator, for example, patents, copyright and trademarks, which enable people to earn recognition or financial benefit from what they invent or create. By striking the right balance between the interests of innovators and consumers, the intellectual property system aims to foster an environment in which creativity and innovation can flourish [2].

According to Fisher [3] intellectual property rights is critical to fostering innovation. Without protection of ideas, businesses and individuals would not reap the full benefits of their inventions and would focus less on research and development (R\&D). Owners of rights can prevent unauthorised use of their intellectual property, to stop copying, to control distribution, and to retain, license or sell their intellectual property [4].

Protecting an invention is one of the key roles that intellectual property rights plays in innovative business ventures [5]. To remain ahead of competitors, business owners must either continuously introduce radically new products and services or make improvements to the quality of existing products and services [6]. Changes are also made in response to customer needs; therefore products or services used in daily life gradually evolves as a result of a series of big or small innovations, such as changes in design or improvements in a product design, packaging and function [7].

Business owners are concerned with maintaining consistent quality and marketing products and services to consumers [8]. Knowledge, both original and new, is essential to all of these processes. The intellectual property rights system is essential to successful management business assets [8]. The main types of intellectual property rights are (1) patents (for inventions), (2) trademarks, (3) industrial designs, (4) valuable undisclosed information or trade secrets, and (5) copyright which includes literary and artistic work.

\section{Protecting intellectual property in Nigerian Business Environment}

Five promiment Nigerian governmental agencies responsible for enforcement of intellectual property rights are (1) National Agency for Food, Drug, Administration and Control (NAFDAC) (2) Nigeria Custom Services (NCS) (3) Standards Organisations of Nigeria (4) Consumer Protection Council (CPC). (5) Nigeria Copyright Commission (NCC).

The Copyright Act (2004) enabled the establishment of Nigeria Copyright Commission (NCC) which is responsible for the administration of copyright and all matters affecting copyright in Nigeria in collaboration with Copyright Societies. The Nigeria Copyright Commission maitains a database of authors and their works, receive and approve applications for copyright licenses [9]. There are influx of substandard and pirated Chinese products in the Nigerian market ranging from mobile phones, DVDs, sportswear including replicas of jerseys of prominent football clubs in Europe such as Manchester United, Arsenal and Barcelona, computer hardwares, textiles etc. Currently, there are 29 cases in Nigerian courts concerning individuals being persecuted for infringements of intellectual property rights [10].

In Nigeria, counterfeiting and piracy affect a huge spectrum of different goods from motor parts to detergents, textile materials, alcohols, perfumes, drugs. No industry is spared from this spate of counterfeiting and piracy ranging from high branded goods to ordinary branded consumer goods-even those as ordinary as toothbrushes.

According to Osunde, 2014, reports from hospitals have shown that hundreds of Nigerians die annually due to the activities of drug counterfeiters.

*Corresponding author: Osunde C, Dean of Studies, Onitsha Business School, Anambra State, Nigeria, Tel: +2347065012259; E-mail: osundecj@gmail.com

Received November 10, 2016; Accepted December 08, 2016; Published December 16, 2016

Citation: Osunde C (2016) Intellectual Property Rights in Nigerian Business Environment: Challenges and Prospects. Intel Prop Rights. 4: 170. doi: 10.4172/2375-4516.1000170

Copyright: (ㅇ 2016 Osunde C. This is an open-access article distributed under the terms of the Creative Commons Attribution License, which permits unrestricted use, distribution, and reproduction in any medium, provided the original author and source are credited. 
A Nigerian, Mr Olisaemeka, an importer of counterfeit drugs worth millions of United States dollars with the collaboration of a cartel based in China was arrested by NAFDAC and charged to court to face the law [11].

\section{Research Method}

This study focused on the importance of intellectual property rights in Lagos State which is the commercial capital of Nigeria. The primary aim of this study is to examine the importance including prospects and challenges of intellectual property rights to micro, small and medium enterprises in Lagos State, Nigeria.

Using a research model developed by [12] the author identifies three main factors or key indicators in this research to determine the importance of intellectual property rights to small, medium and micro enterprises:

\section{Desire and expectations of intellectual property rights}

2. Education and intellectual property rights

\section{Attitudes towards intellectual property rights}

The population of the study is drawn from micro, small and medium businesses in Lagos State. Consequently, the population used for this study consisted of 120 Micro, Small and Medium Enterprises (MSMEs). 115 entrepreneurs operating MSMEs responded to the structured questionnaire. The author used stratified random sampling technique for the purpose of this research to identify the potential respondents.

From the research, $96 \%$ of entrepreneurs responded to the questionnaire while $86 \%$ of highly educated entrepreneurs who were surveyed are aware of the legal aspects of intellectual property rights and desired that their intellectual property was protected from infringements by law. This is a positive outcome of the study.

\section{Results}

The age of the respondents varied from 21 to 57 . However, $70 \%$ of the respondents were over the age of 28 . The level of education among the respondents was fairly low. $32 \%$ of the respondents had attended primary school which is a basic form of education in Nigeria. $52 \%$ stated that they had no basic form of education but received vocational

training from peers and non-governmental organisations (NGOs). $8 \%$ of the respondents had completed their secondary school education while $8 \%$ of the entrepreneurs who responded to the questionnaire had completed their university education. The entrepreneurs involved in operating their businesses were at very different stages if one considers the time they had been conducting their businesses. They were, however, fairly evenly segregated between those who had commenced their businesses less than 4 years ago and those whose enterprises had lasted longer than 4 years.

All of these business ventures engaged by entrepreneurs in the selected population in Lagos State, Nigeria can be referred to as Micro, Small and Medium Enterprises considering the size, number of employees and turnover of their enterprises. $25 \%$ had only one employee (the entrepreneur), 30\% had 8 employees, $40 \%$ had 25 employees and $5 \%$ had above 35 employees. The largest firm, in terms of employment, had 78 employees. It was difficult to convince the entrepreneurs involved in this present research to divulge details of their annual turnover. There were differences in the levels of annual income ranging between N75, 000 or US $\$ 3846$ to N13, 034,000 or US $\$ 34,300$. In only 10 firms was the turnover of above N40, 204,000 or US $\$ 105,800$.

The respondents were asked to mark (on a scale: 1-extremely important to 5 -fairly insignificant) how important they felt the given factors to as entrepreneurs [12] (Table 1).

The two most important factors were quite distinctive. 95\% of the respondents felt that it was extremely or very important for an entrepreneur to have a minimum knowledge of intellectual property rights. Most of the other factors were also considered to be at least fairly important. Who is responsible for intellectual property rights administration factor seemed, however, to be somewhat less significant than the others under intellectual property rights especially for the less education entrepreneurs. Only $20 \%$ regarded this factor as extremely or very important.

The entrepreneurs were given a list of aspects of intellectual property rights and they were asked to rank them in order of importance (1- the most important, 2- the second most important 8- the least important) [12] (Table 2).

Also, $70 \%$ of the entrepreneur respondents stated that innovations

Minimum I should know about intellectual property rights

What rights does the intellectual property owner have?

Can a work benefit from more than one protection

How should I protect my IPRs in a joint development project?

What is meant by a license?

What is the minimum I should know about industrial property?

What are the laws covering Intellectual Property Rights in Nigeria?

Who are responsible for Intellectual Property Rights administration in Nigeria?

Table 1: These factors are listed in order or scale of importance, according to their mean.

\begin{tabular}{|l|c|c|}
\hline & Mean & Standard Deviation \\
\hline & 3.75 & 1.936 \\
\hline & 3.50 & 1.871 \\
\hline & 2.85 & 1.688 \\
\hline ? & 2.70 & 1.643 \\
\hline & 2.45 & 1.565 \\
\hline
\end{tabular}

\begin{tabular}{|c|c|}
\hline Mean & Standard Deviation \\
\hline 7.80 & 2.793 \\
\hline 4.78 & 2.186 \\
\hline 4.56 & 2.135 \\
\hline 9.46 & 3.076 \\
\hline 6.50 & 2.550 \\
\hline 5.75 & 2.398 \\
\hline 1.80 & 1.342 \\
\hline
\end{tabular}

Table 2: The final list of in order of their importance according to them were as follows.

e owner obtains reasonable intellectual property rights to support innovations in the business.

Increase in the overall profitability and returns on capital.

Renewal of intellectual property license.

Higher quality products

Consumer confidence

Business growth through innovation

Business growth through increase in the number patents 
to increase the survival of business ventures were among their business goals. Also, high quality products were ranked amongst the top important factors according to $95 \%$ of the respondents which implies that micro, small and medium enterprises faces a very competitive business environment. This brings to the fore the importance of intellectual property rights.

Business growth through the increase in patents was the least important factor for the entrepreneurs obviously because the business owners felt that a significant increase in patents or intellectual property rights could lead to increase costs for their enterprises.

\section{Managerial Implications}

Highly educated entrepreneurs were very likely to seek intellectual property rights and considered protection under IPR very important. Awareness on the importance of IPR to businesses is one of the key challenges that confront governmental agencies in the enforcement of IPR in the Nigerian Business Environment.

Entrepreneurs should protect their innovations through intellectual property rights which serve the following purposes:

- Protect it against infringement by other individuals or businesses

- Stop their use, production or sales without permission

- Earn royalties by licensing it

- Exploit it through strategic alliances and partnership

- Raise funds by selling the intellectual property rights

Intellectual property rights (IPR) contributes enormously to a country's economy. Industries rely on the adequate enforcement of their patents, trademarks, trade secrets and copyrights, while consumers use IPR to ensure they are purchasing safe and guaranteed products.

\section{Conclusion}

Intellectual property rights are embraced by industries including micro, small and medium enterprises and consumer groups, trade associations and labour unions. Customer needs and competitiveness can drive innovations which are better protected by intellectual property rights. Products or services used in daily life gradually evolve as a result of a series of big or small innovations, such as changes in design or improvements in a product's design and function. Business owners are concerned with maintaining consistent high quality to consumers. Intellectual property rights, therefore is essential to sustain innovations, growth and productivity.

\section{References}

1. Cela M (2014) The Effectiveness of Using Movies in the EFL Classroom - A Study Conducted at South East European University. Academic Journal of Interdisciplinary Studies MCSER Publishing Rome Italy 3: 279-285.

2. Saha CN, Bhattacharya S (2011) Intellectual property rights: An overview and implications in pharmaceutical industry. J Adv Pharm Technol Res 2: 88-93.

3. Fisher W (2001) Theories of Intellectual Property New Essays in the Legal and Political Theory of Property (Cambridge University Press 168-199.

4. Zhengzhi W (2014) China Intellectual Task Force Members 1-40.

5. OECD (2011) Intellectual Assets and Innovations: The SME Dimension OECD Studies on on SMEs and Entrepreneurship OECD Publishing Paris.

6. Akkucuk U, Teuman B (2016) Assessing service quality in online banking services Problems and Perspectives in Management 14: 183-191.

7. Cohen WM, Nelson RR, Walsh JP (2000) Protecting their Intellectual Assets Appropriability conditions and why U.S. manufacturing firms patent (or not) NBER Working Paper 7552.

8. Akkucuk U, Esmaeili J (2016) The Impact of Brands on Consumer Buying Behavior: An Empirical Study On Smartphone Buyers. International Journal of Research in Business and Social Science 5: 1-16.

9. Akkucuk U, Artemel MN (2016) Patent Data Visualization: A Regional Study International Journal of Research in Business and Social Science 5: 66-79.

10. Anthony AT, Chinedu ES (2015) Journal of Law Policy and Globalisation 3 56-61.

11. Osunde C (2014) Managing the Risks of Business Ethics in a Nigerian Environment 2: 33-38.

12. Reijonen $H$, Komppula $R$ (2007) Perception of success and its effect on small firm performance. Journal of Small Business and Enterprise Development 14: 689-701. 